\title{
Vinnie Ream Hoxie at Iowa and Elsewhere
}

\author{
J OH N J. M C D O N A L D
}

In 1873 Mark Twain described a tour through the United States Capitol as part of his satirical commentary in The Gilded Age, that biting novel of political corruption which he wrote with Charles Dudley Warner. As cicerone, Twain advises the tourist to pass up an attractive prospect to be gained by viewing Washington from the Capitol's new dome, because in getting there

... you might have to pass through the old part of the building, and you could not help seeing Mr. Lincoln, as petrified by a young lady artist for $\$ 10,000$-and you might take his marble emancipation proclamation, which he holds out in his hand and contemplates, for a folded napkin; and you might conceive from his expression and his attitude, that he is finding fault with the washing. Which is not the case. Nobody knows what is the matter with him; but everybody feels for him. ${ }^{1}$

The "petrified" Lincoln here isolated for sarcastic attention still contemplates his "laundry" in the Capitol rotunda. Never taken very seriously as a work of art, it has gained anonymity amid the large Capitol collection of unremarkable monuments to political figures, but when commissioned by Congress, it was at least as controversial as Twain suggests, largely because of the "young lady artist" who at last realized $\$ 15,000$ from her labors. This "young lady artist" who benefited so handsomely from Congressional largess was Vinnie Ream, the first woman ever to be awarded a United States government contract for sculpture. She was eighteen when she signed the contract in 1866 .

Vinnie Ream fascinated Washington society from the last year of Lincoln's administration until Garfield's, but the full range of her

1 The Gilded Age: A Tale of To-Day, ed. Bryant Morley French (New York: Bobbs-Merrill, 1972), p. 182 (Chapter 24). 
fascination remains unknown. Her artistic talent was undoubtedly but a minor cause of it. Born in the frontier town of Madison, Wisconsin, on September 25, 1847, she was the third and last child of Lavinia McDonald and Robert Lee Ream. During the late 1850's the Reams led a peripatetic life through varied locations in Missouri and Arkansas, in which area Mr. Ream worked as a government map maker. Near the outbreak of the Civil War, the family moved to Washington, leaving the only boy, Robert, behind in Arkansas. He had enlisted in the Confederate Army. Here began Vinnie's rise to prominence-a rise full of circumstances which start myriad questions, the answers to which promise a vivid picture of social life in Washington from 1861 to 1878. In the latter year Vinnie married a young military officer from Iowa City and began to withdraw herself from Washington's social and political activity.

The keys to discovering how Vinnie rose so spectacularly from the obscurity of her genteel frontier poverty to a position of fame, even notoriety, and some power, lie in the Vinnie Ream and Richard Leveridge Hoxie Papers owned by the Library of Congress. There are ten boxes to this collection, of which nine contain Vinnie's papers. The great bulk of the collection, however, is incoming correspondence rather than Vinnie's own holograph material. For the period 18541873, for example, less than a dozen items written by Vinnie are held by the Library of Congress. Since she evidently kept very few copies of her own letters, the correspondence is too one-sided to be more than a starting place for further search. The social and political status of her correspondents, however, gives promise of significant historical discovery in a final gathering of all the relevant papers. As a fairly random sampling, these correspondents include people like Senator Edmund G. Ross, who cast one of the seven crucial votes against the conviction of President Andrew Johnson after he had been impeached. Thaddeus Stevens, the powerful congressman from Pennsylvania, is there, as are Senator Lyman Trumbull of Illinois (another of the seven Republican votes against Johnson's conviction), Representative James S. Rollins of Missouri, and several other prominent members of the impeachment congress. All this is of more than passing interest because contemporary newspapers often mention Vinnie, then age twenty, as a convincing opponent of impeachment.

When Vinnie was awarded the contract for a full-length statue of the recently assassinated Lincoln, she was also given a room in the basement of the Capitol as a studio. There she set up the bust of Lincoln which she had modelled from life during the last six months of his life. Using it as a starting point, she modelled the rest of her statue 
in clay, working slowly, it seems, because her studio became a popular meeting place for congressmen, senators, cabinet officials, Civil War veterans, diplomats, and journalists-not to mention the fact that the lady had never before even attempted to fashion a full-length statue. During this time, too, she stopped her work to make busts of several prominent studio visitors. Further impeding progress, there was an attempt to evict Vinnie from her Capitol salon in 1868, evidently because it was considered a hotbed of anti-impeachment activity. The eviction, like the attempt to remove President Johnson, failed narrowly.

In the campaign to keep her studio, Vinnie activated correspondence with several American nineteenth-century sculptors, some of whom she had known earlier. The Library of Congress collection includes letters from Henry Kirke Brown, Horatio Stone, and James Wilson MacDonald, all of whom she asked to testify that her statue would be done irreparable harm should she be forced to move it out of the Capitol while still in the clay. Vinnie was not one to abandon useful acquaintances, so these letters are only the first of a lengthy correspondence with artists both in the United States and abroad.

When found and searched, the papers of these people will almost certainly yield many additional facts about Vinnie and, more importantly, about the inner workings of those diverse segments of society that Vinnie knew. Nor are all the letters strictly confined to politics. business, or pleasantry. There is a long series of impassioned letters from Albert G. Pike, often signed only with an asterisk. Pike was a major para-political figure, an important negotiator with several American Indian tribes, a powerful freemason, and a poet of sorts. He was nearly forty years older than Vinnie and had begotten six children, one of whom, his only daughter, appears to have been a close friend to Vinnie. Another constant correspondent and perennial suitor was Elias C. Boudinot, a Cherokee Indian lawyer and businessman who named the rail junction city of Vinita, in the Oklahoma territory, after Vinnie Ream.

The first of two major Vinnie Ream Hoxie items now in the University of Iowa Libraries reveals a completely different side of her character. It is a schoolgirl's copybook in which the first dated entry is October 29, 1855, about a month after Vinnie's eighth birthday. On page [3], however, begins a short essay called "City Scenes, or Passing By," which appears to describe a Washington street scene. ${ }^{2}$ Pages [3942 ], comprising an essay called "Graves," meditate on a visit to "the

2 The copybook is unpaginated. I have assigned page numbers beginning with the first page on which writing appears. 


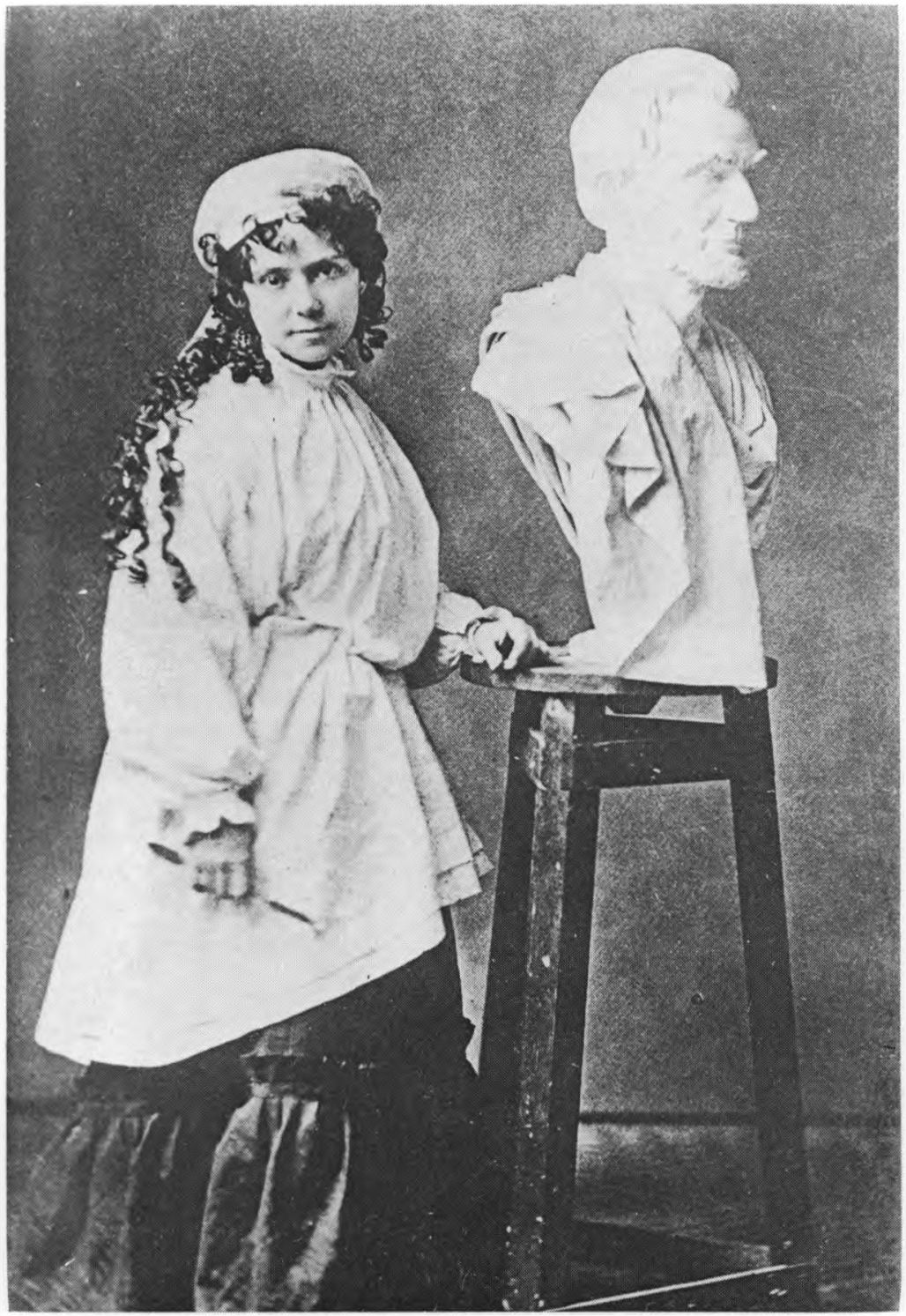

Vinnie Ream, ca. 1866, in her studio in Washington, D.C., with her bust of Lincoln, which had been brought from the White House after the assassination. (Photo courtesy of the State Historical Society of Wisconsin.) 
Congressional Cemetry [sic], which is situated near Washington City." The bulk of this copybook, then, probably dates from her first years in Washington, about 1861-1864. It contains school exercises, like one on "Figures of Speech," and short compositions, of which "Graves" is a fair example. Although there is little specifically personal information here, the book shows Vinnie as an adolescent girl learning conventional lessons in grammar and rhetoric. An unspectacular revelation, perhaps, except that these schoolgirl exercises predate Vinnie's first letters to artists and congressmen by not more than four years. Knowledge of her public life juxtaposed with this testament to her intellectual adolescence puts a central question in high relief: How did this youngster exercise so much influence?

Vinnie was not a highly educated girl. Her only known formal education was a year (1857-58) at the academy section of Christian College in Columbia, Missouri. By the time she applied to Congress for the Lincoln commission, it was abundantly clear that she had talentfor the harp as well as for modelling in clay--but she had never carved marble, nor had she made anything more ambitious than a bust. She did not study anatomy, as Harriet Hosmer did, nor did her family evidently have money with which to buy influence. Why did Congress give her such an important commission-or any commission at all, for that matter? Senator Charles Sumner wondered many of these same things on the floor of the Senate, as did Senator Howard of Michigan, but both of them were branded with one or another term of political opprobrium, and the measure passed with only nine senators voting no. Senator Sumner is a particularly significant figure to have argued against the Ream commission, since he probably knew more about statuary than anyone else in the chamber. He was an early friend to major American sculptors, and his opposition points up the evident fact that the commission was not awarded on grounds of artistic achievement or promise.

Loosely laid into Iowa's Vinnie Ream copybook are several items typical of the kind of thing also found throughout the Hoxie Papers in the Library of Congress. There is an unsigned manuscript poem of sixty-six lines, the handwriting of which suggests a date during the last quarter of the nineteenth century. Vinnie wrote a good deal of poetry, much of it rather in the style of Emmeline Grangerford, Twain's sentimental young writer of graveyard poetry in Huckleberry Finn. Next is a list of newspaper editors. Like many people who orbit Capitol Hill, then as now, Vinnie was seriously attentive to her relations with the press. Her papers abound with lists like this, and the Library of Congress collection includes two bulky scrapbooks of 
newspaper clippings concerning her active Washington life from about 1865. Finally, Iowa's copybook encloses several loose scraps containing lists of names which, like the poem, date from much later in Vinnie's life than the copybook itself. One is on Department of the Interior stationery, dated April 6, 1875, during the time when she was engaged in securing the congressional commission to sculpt Admiral Farragut for the generous sum of $\$ 20,000$.

Whatever the reasoning which led Congress to transform Vinnie from the schoolgirl of her copybook into the maker of those society lists which are tucked into the copybook, the resolution passed, the commission was given. So generous was the contract, in fact, that Vinnie took her family to Europe in the middle of 1869, when the time came to put her Lincoln into marble. After she had completed the clay model, she contracted with a Washington sculptor, Fisk Mills, to cast the whole in plaster, which she then had shipped to Rome for the final transformation into Carrara marble. She was nearly twenty-two years old, and her social success continued unabated while Vinnie and her parents toured England, France, and Germany on their way to Italy. At Paris she met and did a bust of Gustave Doré, who reciprocated by giving her one of his drawings. Here, too, Père Hyacinthe sat for her. In Munich she had the famous German romantic painter Kaulbach as a model.

On October 18, 1869, the Reams arrived in Rome. Within a week Vinnie had taken a studio at 45 Via di San Basilio, in the same building as the midwestern American portraitist George P. Healy. Immediately the young artist with the huge commission set about arranging her studio for both the artistic and social demands of her project. She was enormously successful with the latter arrangements particularly:

The model for the Lincoln Statue-the bust of Gustave Doré, and the likeness of Father Hyacinthe, seem to attract a great deal of attention-I have also in my studio a bust of Mrs Genl Fremont which I made at Paris, and a likeness of the great German painter Kaulbach, which I modeled in his studio in Munich-I have a very large photograph of Mr. Lincoln, surrounded by a wreath of Roman cypress, and the large American flag, (bless it!) festooned over it, and I have two French flags crossed over the Doré bust, and the picture which he presented to me-so you can have some idea of how my studio looks-I have found kind friends here on every side who keep my rooms supplied with a profusion of exquisite flowers, and very frequently on star light nights like these, we are awakened by a sweet Italian serenade-the sere- 
naders brought here, and stationed under our window, by some Americans, almost always- ${ }^{3}$

Many years later, Vinnie remembered the Roman months in idyllic rhapsody:

Oh, those hours in Rome! Those days in Rome-those sunny days on the Campaigna [sic]! Those golden hours when we made pilgrimages to the picturesque and historical towns which make all Italy a gallery. ... They were with me-my parents-oh, happy thought, and what pleasant memories dwell amid the scenes of our wanderings! ... I can never forget those charmed days with their precious associations. ${ }^{4}$

Still, Mrs. Hoxie recalls, Rome was not all tourism:

The day from early morning was given to work, hard work, and at 4 o'clock sometimes my Italian friends-the sculptor Majoli, and the scholar Regnoli, with the ladies of Signor Regnoli's family, would come, and gathering up my parents and myself, take us with them to the open-air theatre or to some one or other of the numberless places of interest in and about the great city whose every inch is filled with monuments and memoirs of the illustrious dead. 5

However hard Vinnie was at work, she did not neglect the social and business necessities of an American artist operating a studio in Italy. She invited the artist community in Rome, both Italian and American, to view her work-particularly, of course, the Lincoln. But a wider audience than that came to visit. Between the first of December, 1869, and October, 1870, at least five hundred different persons trooped through Vinnie's studio to meet this young western sculptress, to view her work, and possibly, to give her commissions for busts or "ideal" works.

Artists' studios in Rome and Florence during the nineteenth century

${ }^{3}$ Letter from Vinnie Ream Hoxie to Mrs. Nealy (?) dated January 26, 1870, at Vinnie's Roman studio. The text is quoted from a typescript copy of the letter made on November 9, 1914, by Mr. Hugh McLellan. This copy is in the Library of Congress Hoxie Papers. The original is mentioned as in the Charles W. McLellan Collection in New York.

4 Vinnie Ream Hoxie, "Lincoln and Farragut," in The Congress of Women, ed. Mary Kavanaugh Oldham Eagle (Chicago: W. B. Conkey, 1894), p. 606.

5 Ibid., p. 607. 
were prime items on virtually every tourist's agenda, second only to the antiquities and public galleries. Virtually all of the guidebooks contain their addresses, and most of the travel memoirs published-they are legion-contain some mention of studio visits. ${ }^{6}$ Some have entire chapters devoted to major expatriate artists like Hiram Powers or William Wetmore Story. What makes Vinnie's studio so interesting in this regard, however, is the fact that she kept a guest book from December, 1869, until some time prior to her leaving Rome in October, 1870. This guest book is the second major item of Vinnie's to be found at The University of Iowa.

Tourists, diplomats, sculptors both Italian and American, painters, musicians, dignitaries from the Roman Catholic Church, and American politicians are all to be found registered in Vinnie's guest book. Not many of the signatures are autographs, since Vinnie or her parents evidently kept the book in order, although a notable exception to this is Franz Liszt, who signed the book with a flourish on April 10, 1870. According to her travel notes on the European journey, Vinnie first met Liszt when she went to hear him play at a convent in Rome on January $7,1870 .{ }^{7}$ Thereafter he several times went to her studio for long visits. She made a medallion of his head and he dedicated a song to her.

From the American artist colony in Rome, Harriet Hosmer, Chauncey B. Ives, Edmonia Lewis, Joseph Mozier, William H. Rinehart, Randolph Rogers, and William Wetmore Story, all prominent sculptors, are registered in Vinnie's guest book. Anne Whitney, Emma Stebbins, Margaret Foley, and Sarah Freeman Clark-less well known women sculptors whom, along with Harriet Hosmer, Henry James called the "white Marmorean flock," all came. So did Charlotte Cushman, the famous American actress now near the end of her life. Among painters registered were George Healy and Miner K. Kellogg, the latter known mostly for an extended public argument over the exhibition of Hiram Powers' "Greek Slave" in the United States during the 1840's. An entry for February, 1870, "Mrs. and Miss Cassatt," almost certainly registers Mary Cassatt and her mother.

There are also "old" friends from Washington, including John Rice, chairman of the House committee which originally recommended Vinnie for the Lincoln commission. Representative James S. Rollins is

6 No guidebook which I have examined, however, has the address of Vinnie's studio. This is, no doubt, because it was open for less than a year.

7 Vinnie's notes on her European trip are in the Library of Congress. They are in the form of a typescript made from a holograph copy. The typist is unknown. but it may have been Mrs. Ruth Norcross Hoxie, who married Vinnie's husband a few years after Vinnie died. 
there, too-he had written a long description of Vinnie's character in recommending her for something, possibly for the original sittings that Lincoln granted her in $1864 .{ }^{8}$ Vinnie had known Rollins since her year in Christian College, shortly before she met Colonel Elias Boudinot, that Cherokee businessman who named Vinita, Oklahoma, for her. He, too, was in Rome at this time.

D. Maitland Armstrong appears twice. He was the American consul in Rome, and was much interested in art. His published memoirs devote a great deal of space to artists in Rome, especially to the early days of Augustus Saint-Gaudens, but he never mentions his visits to Vinnie, even in the catch-all catalogs of American artists which he gives in Day Before Yesterday. ${ }^{9}$

Several newspapermen appear as Vinnie's visitors, usually recorded opposite the names of their publications and the addresses of their editorial offices. Albert Pulitzer is among these. Travelling American military figures, including General Lew Wallace, the wife of General Fremont, and a relative of Admiral Farragut, also appear. At least two American bishops of the Roman Catholic Church were frequent visitors. Especially noticeable is Pittsburgh's Bishop Michael Domenec, who introduced Vinnie to the normally reclusive papal secretary of state, Cardinal Antonelli. The Cardinal was so taken with Vinnie that he sat to her for his portrait bust and later gave her three cameos that had been made in Vatican workrooms.

There is evidence that many of these people later corresponded with Vinnie, so that the gathering of all this correspondence (on both sides) promises a fascinating glimpse into Roman artistic and social life during 1870. As with the young sculptress' earlier life in Washington, during the squabbles over her Lincoln commission, the peculiar value of her correspondence lies in her broad acquaintance. She offers a unique opportunity to examine the way in which an enormous variety of public figures dealt with a peripheral but involved personality. Hers seems to be an assured but outside view, affording wide glimpses of how society functioned around centers of power in the third quarter of the American nineteenth century.

Yet it remains true that the full extent of Vinnie's autograph letters and diaries is not yet known. Bits and pieces are turning up continually-there is some material, for example, at the State Historical Society of Wisconsin and at the University of Missouri Library. The Univer-

\footnotetext{
8 Rollins' character reference is preserved in the Library of Congress Hoxie Pappers.

9 Maitland Armstrong, Day Before Yesterday, Reminiscences of a Varied Life, ed. Margaret Armstrong (New York: Scribner, 1920).
} 
sity of Minnesota has recently made available in microfilm some letters that were found in the papers of Alexander Ramsey. The University of Iowa has recently discovered an additional letter within the correspondence of Charles Edgar Pickett, so that Iowa now has at least three letters in addition to the guest book and the early copybook. The Illinois State Historical Society recently bought a letter concerning the Lincoln statue, and the Schlesinger Library on the History of Women in America, housed at Radcliffe College, has some letters to and from Vinnie and Harriet Hosmer. Certainly much else remains to be found, and the key to finding it lies in such lists of names as are recorded in Iowa's guest book.

Vinnie evidently began her practice of keeping a studio guest book in early 1869, when she had essentially completed her plaster cast for the Lincoln. Container number 8 of the Library of Congress Hoxie Papers has a guest book very similar to Iowa's (though larger), and it was begun about February of that year. A hiatus occurs while the Reams were abroad, after which the book continues naming names until approximately the date of Vinnie's marriage in 1878. Many of the people listed are prominent enough to make it quite probable that their papers have been preserved, and it is in those papers that Vinnie's autograph letters will be found.

One of the principal objects of satire in Twain and Warner's The Gilded Age was the influence which women lobbyists exercised on the post-Civil War congress. The tragic heroine of their disjointed novel is Laura Hawkins, a beautiful orphan from Missouri who nearly makes her fortune via a special congressional appropriation. Instead of gaining success, however, she murders a lover who had surfaced from her Missouri past, and is tried and finally acquitted in a spectacularly histrionic New York courtroom. This, and the exposure of the corruption of her principal Senate supporters, dooms her hope for congressional largess. Destitute, and deprived of political influence, Laura accepts the offer of a Lyceum agent to become a lecturer on women's rights. She fails at this, too, and shortly thereafter dies of the political equivalent to a broken heart.

Vinnie Ream Hoxie is obviously no Laura Hawkins, but it is intriguing to notice some similarities between her career and the kind of social and political satire of Washington that is at the heart of The Gilded Age. One of the names in Vinnie Ream's Roman guest book is James Redpath, John Brown's biographer and a famous Lyceum entrepreneur. In the Library of Congress is found a letter from Redpath. written May 19, 1871, just after the triumphal unveiling of Lincoln in the Capitol rotunda and the congressional appropriation of an addi- 
tional $\$ 5,000$ in appreciation of Vinnie's outstanding achievement:

Dear Miss Ream: Would you be willing to go into the lecture field? I believe you cd make a great deal of money next season by doing so. The great reputation that both your friends \& enemies have given you wd make your success as a lecturer, at the best prices, assured.

Instead of following her fictional parallel, Laura, in this path, Vinnie stayed in Washington and maintained her congressional connections. In 1874 she was again awarded a major government commission, this time $\$ 25,000$ for the bronze monument to Admiral Farragut which still dominates Washington's Farragut Square. This kept her at a center of Washington society until it was completed in 1878, shortly after she married a West Point friend of Farragut's son, Richard Leveridge Hoxie. Thereafter the Hoxies moved about the country a good deal, as Lieutenant Hoxie (later Brigadier General) was transferred from assignment to assignment. Whenever possible, the family stayed in Washington, but the period of Vinnie's Capitol influence seemed now to be over. Most of her summers were spent in Iowa City, which was Hoxie's home town.

There appears to be nothing sinister about Vinnie Ream's exercise of Capitol Hill influence, from whatever sources it may eventually be found to derive. Certainly there is no suggestion of the venality which Twain and Warner satirized in The Gilded Age. On the other hand, most of the material so far published about Vinnie fails to strike any resonant chord in its sentimental picture of a poor girl thrust by overwhelming talent and pure innocence to her just political and financial rewards. Typical of the prevailing approach is an article which appeared some years ago in a magazine published by the Girl Scouts of America. ${ }^{10}$ As documentation for its picture of Vinnie in the guise of a female Horatio Alger, this article refers to Freeman H. Hubbard's Vinnie Ream and Mr. Lincoln (New York: McGraw-Hill [1949]). This juvenile biography gives no indication that it is mostly fiction, which is the case. It even includes, misleadingly, a bibliography of historical works consulted. Hence its "reconstructions" of the nineteenth century can easily be mistaken for the results of faithful and detailed research, which is exactly the mistake that the writer of the Girl Scout article made.

10 Ruth Baker Bowman, "Carving a Career .. . Story of a Young Sculptress Whose Dream Came True," The American Girl, v. 33, no. 2 (February, 1950), pp. 14-15, 40. 
More accurate, and in fact based on some original research, is Gordon Langley Hall's biography, Vinnie Ream: The Story of the Girl Who Sculptured Lincoln (New York: Holt, 1963). As history, however, this book has two serious drawbacks. Like Hubbard's book, it too is pitched to a juvenile audience, and it intends from the start to use Vinnie as a model for emulation. More specifically, Mr. Hall has an admitted and guiding interest in the cause of feminism. The result is a predictable outline of self-reliant womanhood so controlled by the author's thesis that it lacks credibility as useful history.

The usable truth about Vinnie Ream must lie somewhere between The Gilded Age and contemporary portraits of the sculptress. How, in fact, was an untutored young lady, barely past her childhood, awarded a major commission for government sculpture when at least half a dozen Americans were better qualified? The answer to that question, and the answers to questions raised by that answer, promise to unfold a fascinating example of how Congress worked in the period from 1864 to 1871 . Further, the tale will bring to a focus the way in which governmental patronage worked in relation to the nineteenth-century art community. Vinnie, in fact, was the focus of so many different segments of society that her story radiates in dozens of directions. Brought up on the American frontier, an admirer of Lincoln while her brother fought for the Confederacy, she stands at a social and political center of Washington reconstruction culture. In addition she had wide connections with the native and expatriate artistic community, with the press, with freemasonry and Roman Catholicism, with the military, and with the new industrialists. Yet she herself never held any important position that represented more than a passing threat to any of these segments of cultural life. Her papers at Iowa and elsewhere provide a promising nexus from which to glimpse a segment of American life during the third quarter of the last century. 


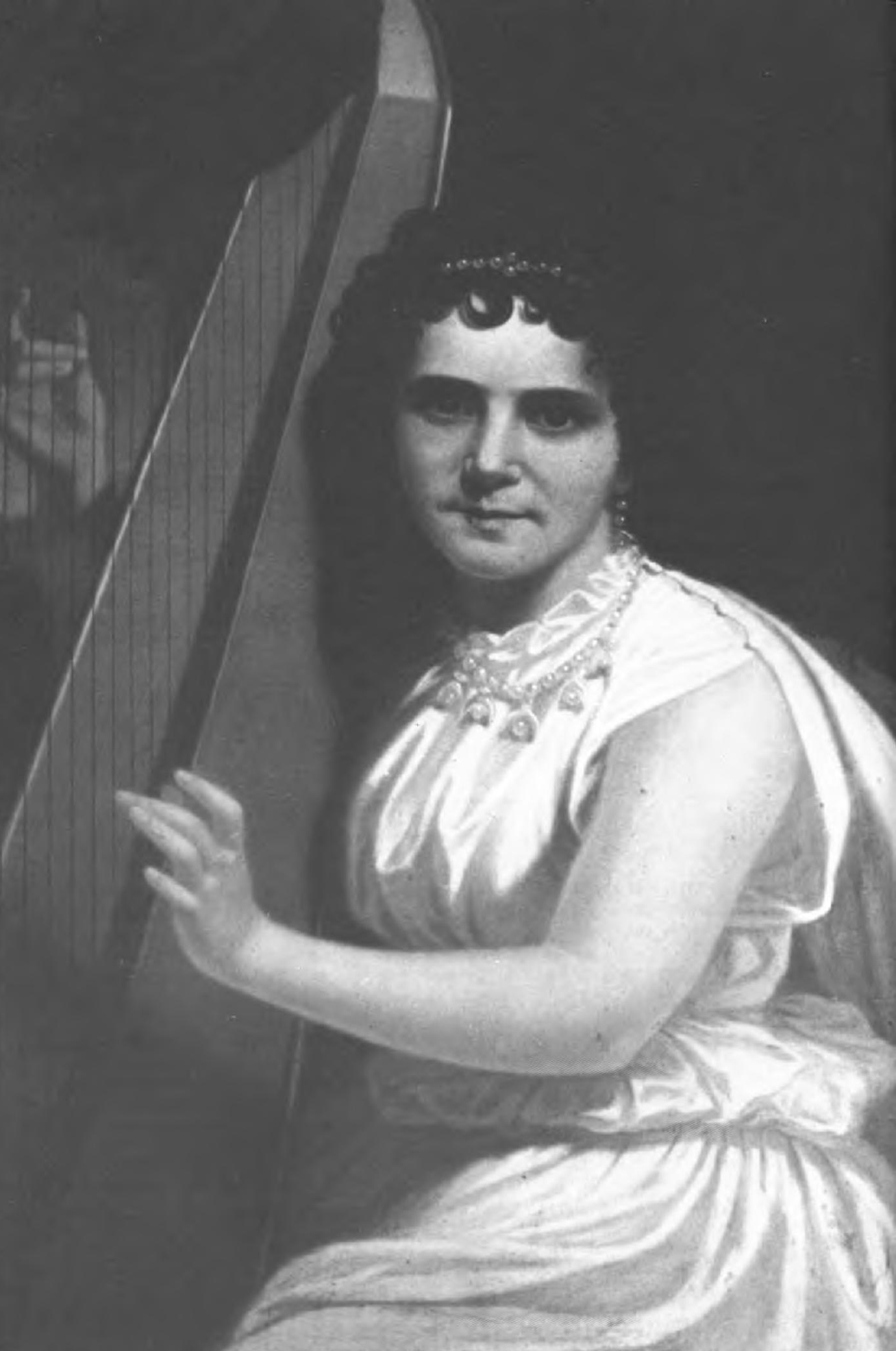

http://ir.uiowa.edu/bai/vol22/iss1 